\title{
Maintenance Task Allocation and Planning in KT. X Tugboat using RCM Method
}

\author{
Dwi Priyanta ${ }^{1}$, Muhammad Badrus Zaman ${ }^{2}$, Apriagung Diantana $\mathrm{P}^{3}$
}

\begin{abstract}
Reliability Centered Maintenance (RCM) as one of the processes that used to decisive action which should be performed to ensure any physical components or a system can work optimally in accordance with the function desired by its users. Basically, RCM used a risk management principles of the failure of the components so that it can be determined the type of maintenance properly. With the appropriate type of maintenance, then the failures that may occur can be prevented at once to be able to be detected before they occur. Appropriate implementation of RCM, capable of delivering cost savings, the impact on both the cost of maintenance as well as repair costs due to the occurrence of failure. In this paper, the components become the object of research is the main engine of the KT. X tugboat belongs to Pelindo Marine Service (PMS) Surabaya. KT. X tugboat has the lowest level of availability of the entire company-owned tugboat 80.01 percent. Tugboat is one of the main assets of PMS who support the economy of the company. Therefore, it is imperative for a company to further enhance the efficiency of activities of its operations. These include the efficiency of human resources, as well as economic analysis of system reliability of company assets. It is used in order to keep abreast of competition at the world maritime national and globally. Implementation of RCM process on main engine KT. X, priority levels can be specified against the failure of components that have critical consequences. So it can be a planned maintenance system generated properly and efficiently.
\end{abstract}

Keywords — failure, main engine, maintenance task allocation and planning, RCM, tugboat

\section{INTRODUCTION}

$\mathrm{S}$ urabaya as an Indonesia eastern gateway makes

Tanjung Perak port in Surabaya as the second largest and busiest port in Indonesia after Tanjung Priok Port, Jakarta. Where the shipping company of the 17 company in the eastern region of Indonesia, 11 of which are centered in the area of Surabaya [1]. On 2015 it was recorded that the port of Tanjung Perak received container as much as 4,360,669 TEUs with the trend of an increase of 0.53 percent from 2014 as much 4,337,555 TEUs [2]. Tanjung Perak Port is one of the ports with the consistency of a dense flow of container in Indonesia. Within 5 (five) years, the flow of container Tanjung Perak Port grew almost 1.5 times of 2.9 million become 4.1 million TEUs [20]. And by 2015, it is estimated there were 66,923 the ship unit which transporting and cargo distribution activities in the port of Tanjung Perak [3]. On 2030, Tanjung Perak Port is projected to be one of the five major ports in Indonesia that will receive the current 9.4 million containers per year [4], see figure 1-2.

In the container traffic flow in the port area, some supporting system are required, including the tugboat. Tugboat services is as a container ship delay service in a dock for the loading and unloading process. As stated in article 2 paragraph 2 subparagraph (a) the regulation of the Minister of transportation number 93 of 2014, the tugboats are used to ensure the safety of shipping and the maritime environment protection in the ships guiding

${ }^{1}$ Dwi Priyanta, Department of Marine Engineering, Institut Teknologi Sepuluh Nopember, Surabaya 60111, Indonesia, Email: priyanta@its.ac.id

${ }^{2}$ Muhammad Badrus Zaman, Department of Marine Engineering, Institut Teknologi Sepuluh Nopember, Surabaya 60111, Indonesia, Email: druz_zaman@its.ac.id

${ }^{3}$ Apriagung Diantana P, Department of Marine Engineering, Institut Teknologi Sepuluh Nopember, Surabaya 60111, Indonesia, Email: apriagungdp@mhs.ne.its.ac.id service in the harbor, its waters and the shipping route [10-11].

Indonesia's President wants the rules of dwelling time or waiting time of ship in Indonesian ports to reach the maximal time of three days. Since the existence of a President's decision in early 2016, Tanjung Perak Port has increased the dwelling time. The increase occurred from the original reach 6.44 day in its early years to the present day 3.45 reached in October 2016 with an average ship in port service has reached 50.16 hours [3].

Tugboat has a vital function in the containers' traffic flow in Indonesia. However this is not accompanied by a high reliability of the tugboat as an asset of the company. Tugboat is categorised as second class ship services with the highest damage percentage rate of 44 percent. The results obtained from the survey as much as 16121 damage occurred on the ships, the second class ship categories suffered as much damage as 7175 ship [6]. During the period of 2008 through June 2012, there were 31 cases or about 32.6 percent of 95 cases of accidents occurred during the process of mooring and anchoring which is done by the tugboat [7].

Therefore, the company need to give a good maintenance management to prevent a breakdown in the tugboat assets. An effective and efficient of maintenance management will optimize the system performance as well as maintaining the life-time of the desired function. Therefore, in this study the writers would implement RCM process with Failure Mode Effects and Criticality Analysis (FMECA) from ABS Rules on the main engine component of the KT. X tugboat which is owned by PT Pelindo Marine Service. The use of RCM properly can reduce the number of maintenance of $40-70 \%$ and will have an impact on cost savings [8]. 


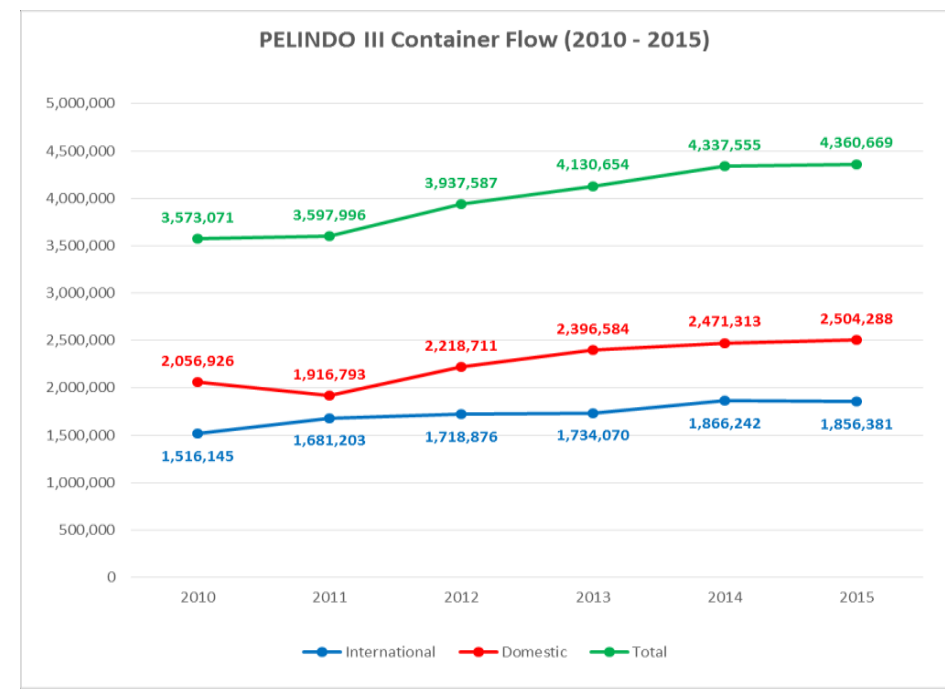

Figure 1. Pelindo III Container Flow From/To The Port Of Tanjung Perak

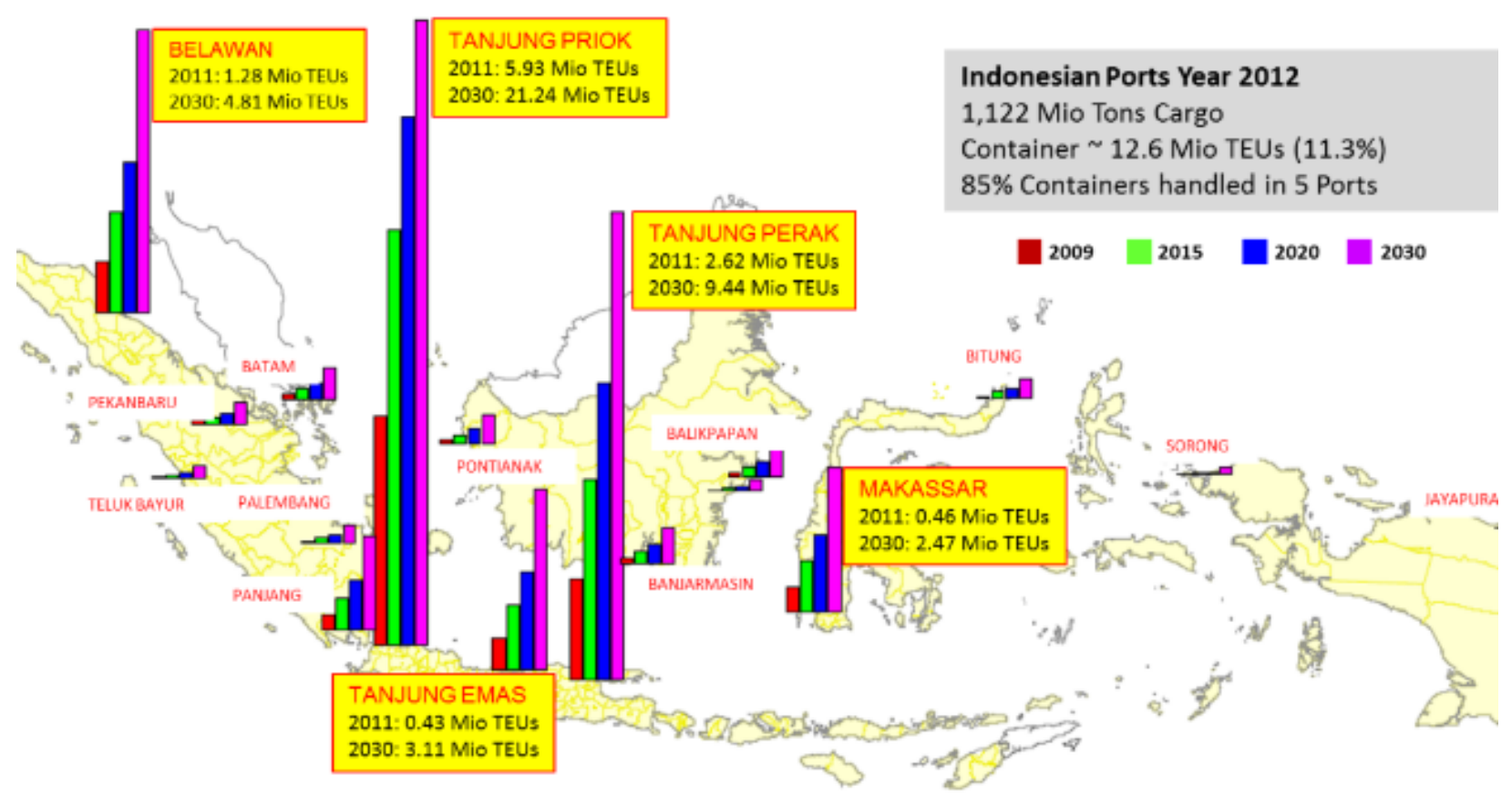

Figure 2. Brief Perspective on National and International Shipping Network in Indonesia on 2030

Basically, RCM answers the 7 questions of main facilities which are examined. Those seven questions are as follows:

1) What is the function and the relation of a standard performance of equipment in operational context at this time (the system function)?

2) How do the equipment fail to operate its function (functional failure)?

3) What caused the occurrence of the failure (failure modes)?

4) What happens at the time of failure (failure effect)?

5) How do the damage influence each other (failure consequence)?

6) What can be done to predict or prevent the failure respectively (proactive task and task interval)?

7) What do to be done if the proper proactive activities cannot be found successfully (default action)?
RCM processes of ABS rules can be used to determine the level of failure as well as the appropriate treatment plan of each component. Where the later is expected to help the planned treatment system on board with not disrupting the operational time of the ship. Moreover, priority scale can be determined to maintain the components, especially for the components which has the important function.

This paper is organized as follows. In the first section, the writers introduce the background of this research. In the second section, the writers present review of related literatures. In the third section, the explanation step of Reliability Centered Maintenance (RCM) analysis was conducted. Then, the fourth section is Result and discussion. The results of an analysis of Failure Mode, Effects and Criticality Analysis (FMECA) from ABS Rules were explored. Finally, the last section was the conclusion of implemetation of RCM. 


\section{METHODOLOGY}

\section{A. Study Case}

This step is identification and accumulated of the problems that exist in the ship. The object of research of this paper that is taken at the main engine on KT. X tugboat of PMS owned. The operation of the vessel in accordance with its functions optimally strongly supported by the performance of the entire system on the ship. Main engine is one of the main components in the ship's operational support ships, as a driving force of the ship or the safety of the ship. So that the component can work optimally required of optimally maintenance so the potential occurrence of a failure can be reduced.

In Figure 3, explained that KT. X has the lowest level of availability of the tugboat PMS. With the value of the availability of 80.01 percent [18], then it can be inferred that KT. X have a higher duration time of breakdown. Based on historical repair of KT. X during inr 2016, most of the demand for improvements made to the main components of the engine.

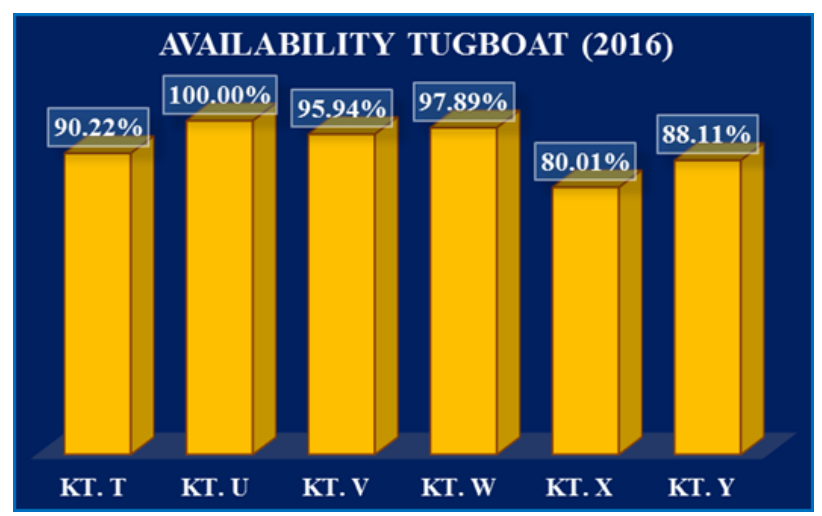

Figure 3. Tugboat Availability of PMS on 2016

In this paper, analysis of the failure of the main engines of the vessel was done qualitatively by the Reliability Centered Maintenance (RCM) method. But how is the risk of failure may occur and the extent of the impact inflicted on the ship operational, it needs to be carried out an analysis of the failure i.e. Failure Modes, Effects and Criticality Analysis (FMECA) using the ABS Rules for stating the failure into categories. Further analysis conducted maintenance task allocation and planning on the component.

\section{B. Collecting Data}

Basically the data required for analysis by the RCM method on this paper qualitative data to support or answer questions which refers to RCM ABS Rules. On the working of this paper, the author does observation to Pelindo Marine Service of Surabaya in obtaining data from the KT. X so that the data used for the analysis of the RCM, among others:

1) Specifications data and system components include design and construction drawings (engineering and component specification) used to know in detail the condition of the ship. The data of the specification and ship system components are taken from a book of Instruction and Maintenance manuals, Manufacture Guideline and direct observation on KT. X Pelindo Marine Service owned.

2) To evaluate the reliability of the components of the ship needed design system or initial design. The initial design referred to in this research is the design system of the ship KT X. With the data design system then it can be known to be located on the system where the component.

3) Operational ship time data and main engine data when the failure is occurance, repair or maintenance during the period of time to evaluating the reliability of the components of the ships. In this case data retrieval be operating hours are limited for one year (2016). The data obtained from Pelindo Marine Service.

4) Historical repair data that used to find out the history of failure and repair list from main engine KT. X tugboat that has the potential risk of failure and identify the appropriate type of maintenance the fortunes for each component. The data is taken from the data repair belonging to Pelindo Marine Service during the year 2014-2017.

\section{Functional Hierarchy Components Identification}

Asset register is the process of putting together the assets owned by the company based on its function in the system. Register of assets required as supporting treatment of the entire process of owned assets. NORSOK standard Z-008 revised 2011 put assets as resources prior to operational work. It is compiled a list of component based on its function and each component has the form code and different number [16].

\section{Failure Mode, Effects and Criticality Analysis (FMECA)}

Failure analysis of main engine KT. X tugboat is done with Failure Modes, Effects and Criticality Analysis (FMECA) by using the RCM methods of ABS Rules [1]. As for the steps in implementing the FMECA in this research are as follows:

1) Identification Of The Operating Mode And Operating Context

In this study the operating modes are classified into four categories namely at sea, in congested waters, maneuvering alongside and cargo handling. Where in four categories there are three main characteristics, namely the Environmental Parameters, the Manner of Use, and Performance 
Capability. Operating context in this research are determined based on the results of the interview with engineering management and operations management from PMS. Based on the results of the interview obtained data on the operational time of work of tugboat KT. X along with any specification of the expected work appeared in its operations.

2) Identification of Functional Failure and Failure Effect

Based on the data of ship particular and project guide of main engine obtained from PMS, can be determined functional failure of the main engine. Analysis of failure data required addition data such as books, paper, maintenance manual guideline from the main engine and the historical data repair has been documented before
3) Identification of Failure Mode

Failure mode is the cause of the failure that is capable of causing the failure of the function (functional failure). In this paper, a list of history repair or failure which have been experienced by KT. X tugboat during 2016 is used as the list of failure mode analysis to be performed FMECA.

4) Critical Equipment

One of the outputs of the analysis it is the level of inquiries FMECA components based on the risks and effects posed when the failure occurred. In the preparation of FMECA needed some standard include Severity Level, Probability of Failure and Risk Matrix [9], see figure 4.

\begin{tabular}{|c|c|c|c|c|c|c|}
\hline Critical & 4 & & \multicolumn{4}{|c|}{ HIGH RISK } \\
\hline Hazardous & 3 & & & & & \\
\hline Major & 2 & & \multicolumn{3}{|c|}{ MEDIUM RISK } & \\
\hline Minor & 1 & \multicolumn{3}{|c|}{ LOW RISK } & & \\
\hline & & \multicolumn{5}{|c|}{ LIKELIHOOD } \\
\hline & & 1 & 2 & 3 & 4 & 5 \\
\hline & & Improbable & Remote & Occasional & Probable & Frequent \\
\hline
\end{tabular}

Figure 4. Risk Matrix

\section{E. Maintenance Task Allocation and Planning}

Maintenance task allocation and planning is the goal of this final project work. In this study the author on the book guided ABS Guidance notes on ReliabilityCentered Maintenance. Maintenance task allocation and planning resulting from the analysis of RCM is divided into several categories according to the location and the required maintenance activities in, among others:

1. Category A (performed by the vessel crew)

2. Category B (needs to be accompanied by the vendor of the components)

3. Category $\mathrm{C}$ (done on dry dock facility)

In this stage, the analysis was conducted based on the results of the analysis of the FMECA. Based on the results of the analysis specified proposed actions or recommendations or corrective actions undertaken against treatment failures occur. Expected with the enactment of proposed actions properly, then the condition of the components can be returned as they are or to meet specific needs of the component itself. In drafting the proposed actions contained task interval or frequency. Task interval or frequency is a period of time or the schedule of an operation or treatment performed on each component. Task interval are derived from analysis of the RCM does not need to correspond to the treatment schedule (calendar-based maintenance schedule). This needs to be integrated with existing maintenance schedules due to task intervals can be done either shorter or longer than the existing schedule [2].

\section{RESULT AND DISCUSSION}

\section{A. Failure Mode, Effects and Criticality Analysis}

Pelindo Marine Service (PMS) is a subsidiary of Indonesia Port Company III which moves and synergizes to provide maximum services in the field of shipping services. One of the shipping services provided by STD company is guiding and delaying services used tugboat vessels. Thus, the tugboat is one of the main assets of companies that support the productivity of the company. If there is a damage in the tugboat operations, it will cause the stopping of productivity or existing businesses in the company and have a direct impact on the company's income.

Every day, the tugboat owned by PMS as a subsidiary of IPC III are required to be able to stand by for 24 hours due to fulfill operational duration of assets which have been set. In that time, each of ship has an operational time depends on the task list compiled by operations management to fulfill each day of the delay services of the ship. So in in 1 month ( 31 days), a tugboat owned by PMS are required to be able to stand by during the 744 hours and 8760 hours in a year.

$\mathrm{KT}$. X is one of the assets belonging to the company that has the lowest level of availability of 80.01 percent. It can be concluded that in $2016, \mathrm{KT}$. X only be able to stand by or operating for 7143 hours. This low level of availability is an indicator that KT. X suffered some damage or repair comparing to the other tugboat for 2016. So that by 2016 , KT. X has breakdown time or high non-operation period and resulted in a fairly low 
level of availability of the ships. It will directly affect the company's financial because PMS will obtain a fine as the consequence they cannot reach the maintained target. This fine will be accumulated based on calculations from the non operating tugboat for a year. Based on those problems, the KT. X is chosen as the object of this research with the following data on table 1.

TABLE 1.

General SpecificAtion of KT. X Tugboat

\begin{tabular}{|c|c|c|c|}
\hline \multicolumn{2}{|c|}{ GENERAL } & \multirow{2}{*}{$\begin{array}{c}\text { Length Overall } \\
\text { Length } \\
\text { Perpendicular }\end{array}$} & \multirow{2}{*}{$\frac{32 \mathrm{~m}}{30.5 \mathrm{~m}}$} \\
\hline Vessel Name & KT. X & & \\
\hline Kind of Vessel & Tug Boat & Breadth Moulded & $10.4 \mathrm{~m}$ \\
\hline Owner & $\begin{array}{l}\text { Pelindo } \\
\text { Marine } \\
\text { Service }\end{array}$ & $\begin{array}{c}\text { Depth Moulded } \\
\text { Draft }\end{array}$ & $\begin{array}{l}5 \mathrm{~m} \\
3.5 \mathrm{~m}\end{array}$ \\
\hline GT & 371 & Speed & 12 knots \\
\hline
\end{tabular}

Based on the historical repair data, the damage tends to occur on main engine components. So in this study, the components that will be analyzed is focused on the main engine. The damage data which is used is found in the historical repair KT. X during 2014-2017. Main engine is one of the major components of the ship as a producer of power for propulsion system in order to activate the ship. There are two main engine in the KT X which operate side by side. In this study, the components which is used as the object of this study is the main engine of the KT.X with the following specifications in table 2 .

TABLE 2.

General Specification of Main Engine Tugboat KT. X

\begin{tabular}{cc}
\hline & MACHINERY \\
\hline Main Engine & 2 units of Marine Diesel Engine, Caterpillar \\
Engine Output & $2 \times 1800 \mathrm{~kW}$ \\
Engine Speed & $2 \times 720 \mathrm{RPM}$ \\
\hline
\end{tabular}

Considering there are many complex system in the vessels, it is needed to classify into the function system. In this study, the function classification uses the NORSOK standard Z-008 revised in 2011. The classification is done based on group functions, specific systems, sub-systems and components (equipments) as shown in Figure 5-6.

The next step is the identification of the functions/characteristics/specifications of the main engine. This stage is carried out to find out the existing functions and expected owner against the main engine and the occurrence of its failure. The function identification of the main engine can be done by guided data specification of manufacturing and owner requirements. In this study, there were 20 points of functional failure from the main engine which is defined as the main engines inability to fulfil the required performance by Pelindo Marine Service. It includes specification, power output and rounds from the main engine. 


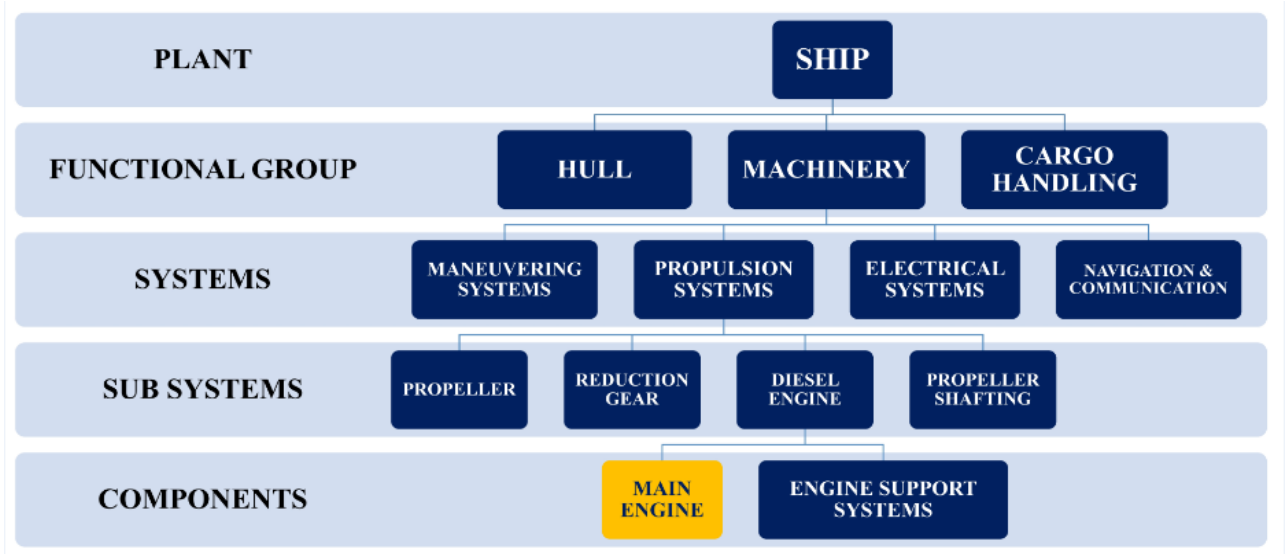

Figure 5. Functional Hierarchy of Main Engine KT. X

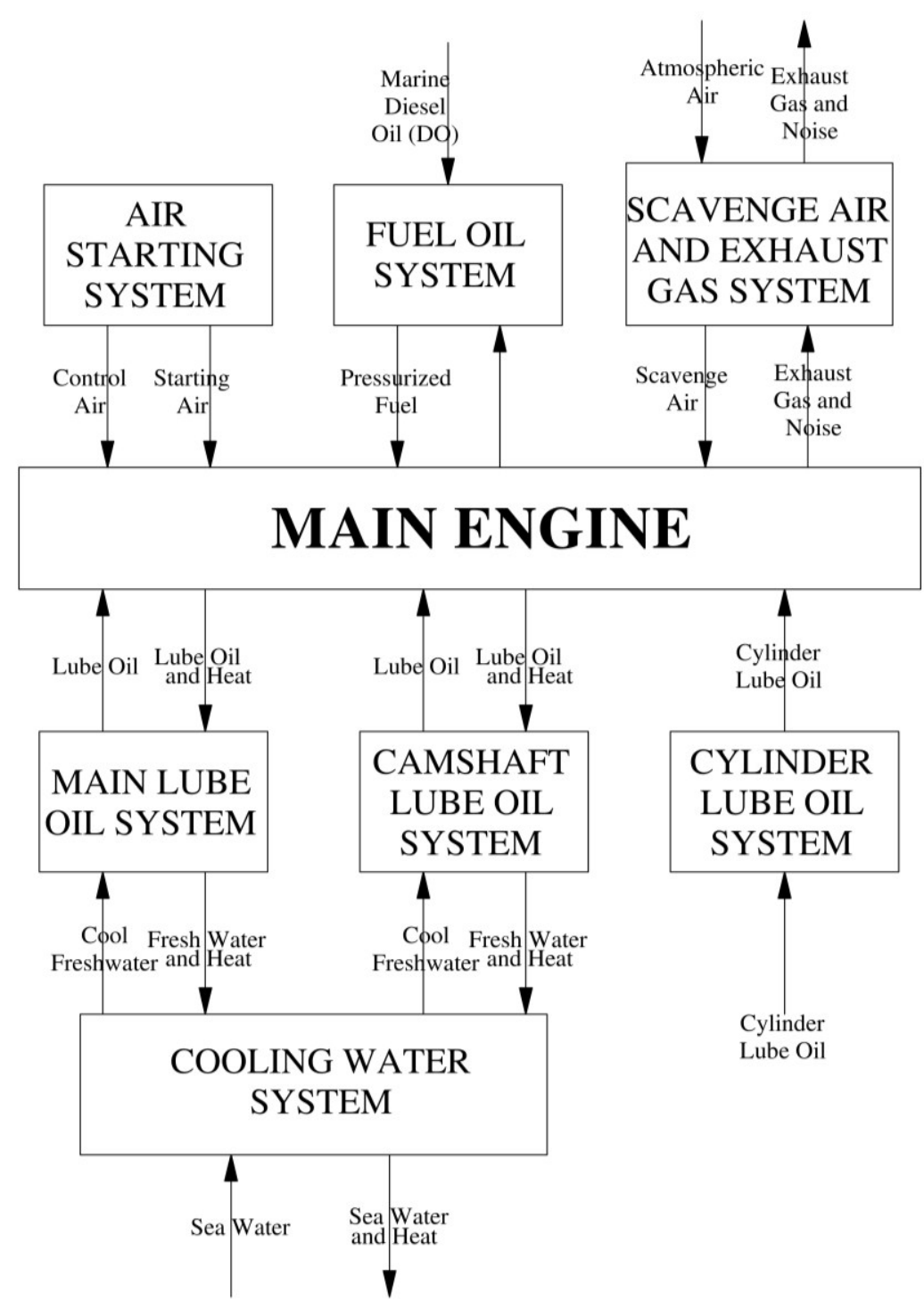

Figure 6. System Block Diagram of Main Engine KT. X

In this study there were 31 list of failure modes which were done by FMECA and maintenance task allocation and planning. Then, it needed to identify failure effects which was occurred based on those failure mode through three stages, namely the causes, local effects, and end effects. In this study, failure effects in each failure modes were obtained from block system identification diagram. So, there were interrelatedness effects on each components which may occur if there is a failure.

Moreover, determining the critical level in each failures which is occurred using risk matrix table. At this stage, critical matrix of component failures is combination function from the frequency of failure types (current likelihood) and the critical deterioration level of the failure which may occur (severity). Based on the FMECA analysis, the percentage of the risk level of the 
damage that occurs in main engine $\mathrm{KT}$, amounted to $37,5 \%$ are at "high risk" level and $62,5 \%$ are at a risk level "medium", see figure 7.

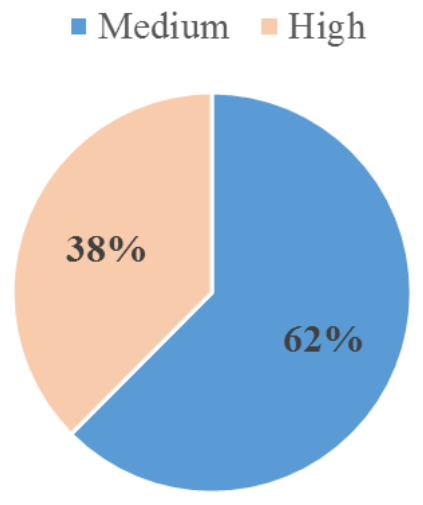

Figure 7. Risk Level Percentage of Failure Mode

\section{B. Maintenance Task Allocation and Planning}

When FMECA analysis has been done, the next step is analysis of the maintenance task allocation and planning. At this stage, the identification of failure modes in terms of the type of failure (hidden or evident failure) as well as proposed actions to each failure mode is done. Hidden or evident failure will explain that the failure gives directly or indirectly effects against the performance of the system. From the results of the analysis of maintenance task allocation and planning, there are failure types level as presented in Figure 8.

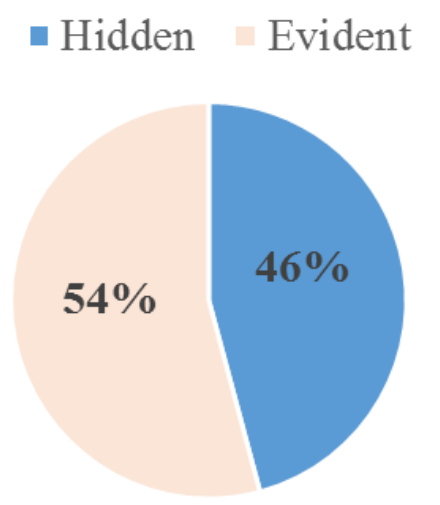

Figure 8. Percentage of Hidden or Evident Failure

\section{Proposed Actions}

The purpose of this analysis was to determine the proposed actions or necessary actions to identify or fix the failures that occur based on predetermined standards. In this research proposed actions using the standard ABS Rules. In addition, in determining the proposed actions of a failure mode, it required supporting data such as books, paper, maintenance manual guideline from the main engine and the historical data repair which has been documented before.

Then, based on the analysis results of maintenance task allocation and planning, will be summed up into a summary of maintenance task. In this stage, each failure mode has been identified into the maintenance actions (task list) to be performed and the selection policies of maintenance (task selection). Task selection is done to determine a treatment decision or action which is applied into the kind of proper, effective and efficient maintenance (task type).

Effective action means that the maintenance actions is expected to detect failures that will occur or find hidden failure. So in its operation, the failure can be prevented and addressed properly. Efficient means that treatments have an economic value or a profit when it is seen from a comparison of the total cost of maintenance (maintenance cost) with the costs incurred in the damage occurrence (repair cost).

Every action of the recommended treatments to overcome failure mode that occurs on the FMECA analysis will be divided into several categories. This designation in accordance with the type of treatment or (task type) the right based on the results of the research (maintenance recommendation). Among them is a kind of care preventive maintenance (PM), condition monitoring $(\mathrm{CM})$, failure finding $(\mathrm{FF})$ and one-time change (OTC). Stages in this type of treatment is based on the logic tree analysis in the book the ABS Guidance Notes On Reliability-Centered Maintenance. Logic tree analysis on phase summary of maintenance task presented in Figure 9. The following is a summary of results from the maintenance task is shown in table 3 . 
TABLE 3.

ReCAPItUlation In the Summary Of Maintenance TASk Stage

\begin{tabular}{ccc}
\hline \multicolumn{3}{c}{ Percentage of Maintenance Category } \\
\hline \multirow{2}{*}{ Maintenance Category } & \multicolumn{2}{c}{ Failure Mode } \\
\cline { 2 - 3 } & Number of & Percentage (\%) \\
\hline A & 45 & $59,21 \%$ \\
B & 20 & $26,32 \%$ \\
C & 11 & $14,47 \%$ \\
Amount of Tasks & $\mathbf{7 6}$ & $\mathbf{1 0 0 , 0 0 \%}$ \\
\hline
\end{tabular}

Each treatments (tasklist) are categorized into three categories based on parties, procedure and place where the treatments has done. Based on table 3 presented that at the category A has a percentage there are 59,21\% with 45 tasklist, category B has a percentage of $26,32 \%$ with 20 tasklist, and category $\mathrm{C}$ has a percentage $14,47 \%$ with 11 tasklist.

" $A$ " category is a category in which every action tasklist can care and allowed to directly carried out or performed by the clerk of the ship or crew care itself (vessel crew). Category " $\mathrm{A}$ " has the highest percentage due to most of the recommended maintenance actions to be done can be done at the time by the vessel crew without the need to be accompanied by a surveyor, a complex piece of equipment vendors, or dry dock facility.
In addition, actions that fall into the category of " $\mathrm{A}$ " treatment is an activity that is done on a regular basis and continuous throughout its operational period in tugboat. So it is the duty and responsibility of the owner of the ship which in this case was done by the crew of the ship itself. The stage summary of maintenance tasks, each act of care (tasklist) conducted an analysis to determine the type of treatment (task type). Any tasklist categorized into each type of treatment based on logic tree analysis in the book the ABS Guidance Notes on ReliabilityCentered Maintenance. Following is the result of the determination of the types of care (task type) from the stage of a summary of maintenance task is shown in table 4-6. 


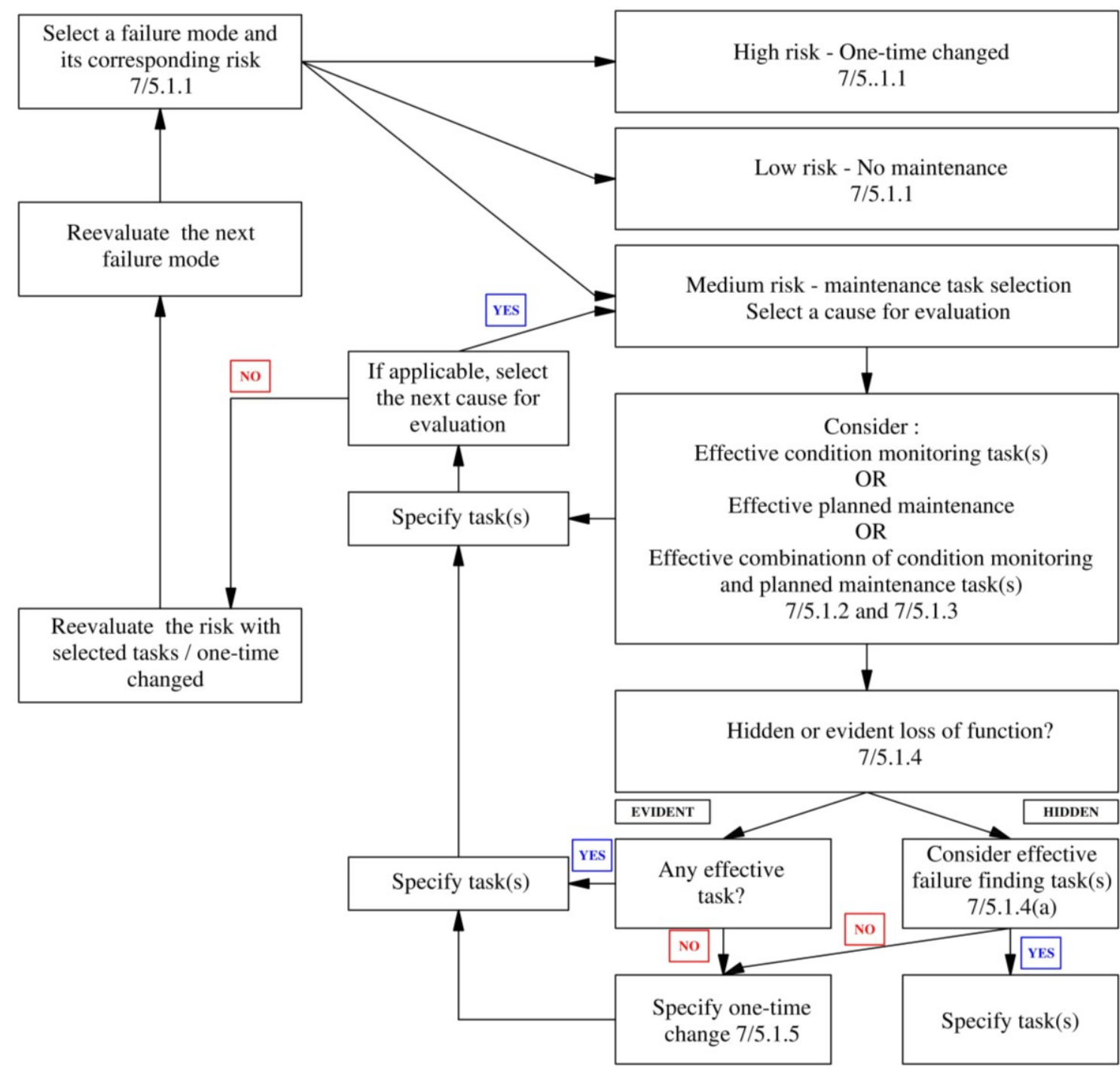

Figure 9. Logic Tree Analysis For Task Selection

Based on table 4, presented that in category A that is the category with the highest number of tasklist, also have the kind of treatment with preventive maintenance categories (PM) most among other categories.

This type of treatment is preventive maintenance has a high amount due based on the results of the analysis of the treatment recommendations there are several new tasklist is expected to support the reliability of each component in its operational period.
In the next step, a comparative analysis was done (the study comparison) the results of the analysis of the treatment recommendations made by the author (maintenance recommendation) against treatments that have been done in the field (the existing maintenance) on each component undertaken analysis of RCM. The results of the analysis on the study comparison was presented in table 7 .

TABLE 4 .

TASK TyPe ReCAPITULATION ON EACH MaINTENANCE CATEGORY A

\begin{tabular}{lcc}
\hline \multicolumn{3}{c}{ Maintenance Category A } \\
\hline Task Type & $\begin{array}{c}\text { Number } \\
\text { of }\end{array}$ & Percentage (\%) \\
\hline Preventive Maintenance (PM) & 22 & $28,95 \%$ \\
Condition Monitoring (CM) & 15 & $19,74 \%$ \\
Failure Finding (FF) & 4 & $5,26 \%$ \\
One-Time Change (OTC) & 4 & $5,26 \%$ \\
Number of Tasklist & $\mathbf{4 5}$ & $\mathbf{5 9 , 2 1 \%}$ \\
\hline
\end{tabular}


TABLE 5 .

TASK TyPe ReCAPITULATION ON EACH MAINTENANCE CATEGORY B

\begin{tabular}{lcc}
\hline \multicolumn{3}{c}{ Maintenance Category B } \\
\hline \multicolumn{1}{c}{ Task Type } & $\begin{array}{c}\text { Number } \\
\text { of }\end{array}$ & Percentage (\%) \\
\hline Preventive Maintenance (PM) & 8 & $10,53 \%$ \\
Condition Monitoring (CM) & 0 & $0,00 \%$ \\
Failure Finding (FF) & 11 & $14,47 \%$ \\
One-Time Change (OTC) & 1 & $1,32 \%$ \\
\multicolumn{1}{c}{ Number of Tasklist } & $\mathbf{2 0}$ & $\mathbf{2 6 , 3 2 \%}$ \\
\hline
\end{tabular}

TABLE 6.

TASK Type Recapitulation on Each Maintenance Category C

\begin{tabular}{lcc}
\hline \multicolumn{3}{c}{ Maintenance Category C } \\
\hline \multicolumn{1}{c}{ Task Type } & $\begin{array}{c}\text { Number } \\
\text { of }\end{array}$ & Percentage (\%) \\
\hline Preventive Maintenance (PM) & 0 & $0,00 \%$ \\
Condition Monitoring (CM) & 0 & $0,00 \%$ \\
Failure Finding (FF) & 8 & $10,53 \%$ \\
One-Time Change (OTC) & 3 & $3,95 \%$ \\
\multicolumn{1}{c}{ Number of Tasklist } & $\mathbf{1 1}$ & $\mathbf{1 4 , 4 7 \%}$ \\
\hline
\end{tabular}

TABLE 7.

TASK TYPe RECAPITULATION ON STUdy COMPARISON

\begin{tabular}{ccc}
\hline \multicolumn{3}{c}{ Summary of Maintenance Recommendation } \\
\hline Task Type & $\begin{array}{c}\text { Number } \\
\text { of }\end{array}$ & Percentage (\%) \\
\hline Preventive Maintenance (PM) & 30 & $39,47 \%$ \\
Condition Monitoring (CM) & 15 & $19,74 \%$ \\
Failure Finding (FF) & 23 & $30,26 \%$ \\
One-Time Change (OTC) & 8 & $10,53 \%$ \\
Number of Tasklist & $\mathbf{7 6}$ & $\mathbf{1 0 0 , 0 0 \%}$ \\
\hline
\end{tabular}

\section{CONCLUSION}

RCM process as one form of preventive maintenance based on reliability has a purpose to maintain system reliability. RCM run risk management principles of the failure of the components so that it can be determined the type of proper care. With the right type of care we can prevent failures that may occur (failure mode) or to detect it before it happens.

RCM functions to keep the system in order to be always in good shape and find the mode-mode failure which may occur when the system was operational. The management of effective and efficient treatments will produce the optimal system performance as well as maintaining the life-time of the desired function. Therefore, in this study the author would implement process Failure Mode analysis with RCM, Effects and
Criticality Analysis (FMECA) from ABS Rules on the components of the main engines of the tugboat KT. X PT Pelindo owned Marine Service.

RCM of ABS processes rules can be used to determine the level of failure as well as the appropriate treatment plan of each component. Where the later is expected to help the planned treatment system on board with not disrupting the operational time of the ship. Moreover, it can be determined the scale of priority maintenance or maintenance components especially for components that have important functions. 


\section{REFERENCES}

[1] BKPM, “Layanan Jasa Kepelabuhan Di PT. Pelabuhan Indonesia III (Persero)", Surabaya: PT. Pelindo III, , pp. 7-11, Apr. 2016

[2] PTSMI, “SMI Insight Triwulan III-2014”, Jakarta: PT. Sarana Multi Infrastruktur (Persero), pp. 8-9, Quartal III. 2014.

[3] NORSOK, "NORSOK Standard Risk Based Maintenance and Consequence Classification". 3rd Edition. Norway: NORSOK Standard, pp. 18-19" Jun. 2011.

[4] KEMENHUB, "Peraturan Menteri Perhubungan Republik Indonesia Nomor : 93 Tahun 2014 Tentang Sarana Bantu Dan Prasarana Pemanduan Kapal”, Jakarta: Menteri Perhubungan

[5] Ebeling, C., "An Introduction to Reliability and Maintainability Engineering". New York: The Mc.Graw Hill Companier Inc, 1997.

[6] KEMENHUB, "Keputusan Menteri Perhubungan Nomor : KM 57 Tahun 2015 Tentang Pemanduan Dan Penundaan Kapal”, Jakarta: Menteri Perhubungan Republik Indonesia. 2015.

[7] ABS, "ABS Guidance Notes On Reliability-Centered Maintenance”, USA: American Bureau of Shipping, 2004.

[8] ABS, "ABS Guide for Survey Based On Reliability-Centered Maintenance", USA: American Bureau of Shipping, 2003.

[9] Corder, A. S., "Teknik Manajemen Pemeliharaan", Jakarta: Erlangga, 1996.

[10] Dhillon, B. S., "Reliability Engineering in System Design and Operation". New York: The Mc.Graw Hill Companier Inc, 1997.

[11] DNV, "Shipping And Offshore Activity Data For Australian Ports And Waters", Australia: Det Norske Veritas, rev.05, pp. I.13, 2011.

[12] F.S. Nowlan, H. H., "Reliability Centered Maintenance". San Fransisco: Dolby Access Press, 1978.

[13] G. Niu, B. Y. M. P., "Development of an optimized conditionbased maintenance system by data fusion and reliability-centered maintenance. Elsevier, 2010.

[14] Republik Indonesia. 2014.

[15] KP3EI, 2013. "Brief Perspective on National and International Shipping Network in Indonesia”, Jakarta: Tim Kerja Konektivitas KP3EI.

[16] Lewis, E. E., "Introdution to Reliability Engineering". 2nd Edition penyunt. s.1.:John Wiley \& Sons, Inc, 1987.

[17] MLIT, "White Paper On Land Infrastructure, Transport And Tourism In Japan", Japan: Ministry of Land, Infrastructure, Transport and Tourism, 2012.

[18] Moubray, J., "Reliabillity Centered Maintenance". 2nd Edition penyunt. New York: Industrial Press Inc, 1997.

[19] PELINDO, 2015. “Laporan Tahunan Pelindo III”, Surabaya: PT. Pelindo III (Persero).

[20] PMS, "Data Availability dan Utilisasi”, Surabaya: PT. Pelindo Marine Service. 2016.

[21] Priyanta, D., “Keandalan dan Perawatan”. Surabaya: Jurusan Sistem Perkapalan ITS. 2000.

[22] Priyanta, Dwi, Nurhadi Siswantoro, "Risk Based Inspection of Gas-Cooling Heat Exchanger". International Journal of Marine Engineering and Innovation Research, vol. 1 no. 4, pp. 317-329, September 2017. 